\title{
A DESIGN OF STANDALONE HYBRID PV/WIND/FUEL CELL GENERATION SYSTEM AND HYDROGEN ELECTROLYZER WITH LOCAL CONTROLLER FOR REMOTE AREAS
}

\author{
Soedibyo \\ Electrical Enginnering Departement \\ Sepuluh Nopember Institute of \\ Technology \\ Surabaya \\ East Java, Indonesia \\ soedib@ee.its.ac.id
}

\author{
Sjamsjul Anam \\ Electrical Enginnering Departement \\ Sepuluh Nopember Institute of \\ Technology \\ Surabaya \\ East Java, Indonesia \\ anam@ee.its.ac.id
}

\author{
Andri Pradipta \\ Electrical Engineering Akademi Perker \\ etaapian Indonesia. Madiun \\ East Java, Indonesia
}

\begin{abstract}
Integration of fuel cell and electrolyzer on DC bus is a promising alternative to solve voltage fluctuation and balance of power problems in a standalone hybrid renewable power generation systems. The hybrid renewable power generation systems consist of photovoltaic, wind turbine, fuel cell and hydrogen electrolyzer. Each the component integrated on DC bus through the converter DC - DC using local controller to supply the inverter which connected to the islanded load. Local controller in each part will make the system become flexible if there are additional generating units in the future. The local control methods used in this hybrid renewable power generation system is MPPT and constant voltage control. MPPT control applied to photovoltaic and wind turbine converters to maximize power generation from photovoltaic and wind turbine. Constant voltage controller applied to the fuel cell and electrolyzer converters to control the DC bus voltage alternately. This research is a new design system for remote areas by utilizing the potensial of renewable energy in the area. The result show the power quality and continuity of electricity services.
\end{abstract}

Keywords-Hybrid, Photovoltaic, Wind turbine, Fuel Cell, Hydrogen Electrolyzer, Local controller

\section{INTRODUCTION}

Development prospect of hybrid renewable energy generating systems in the future is promising. This is due to the need for electrical energy is increasing and hybrid power plant technology is the solution to the dependence on fossil energy. Renewable energy potential in an area can be utilized optimally by performing the power plant system integration. From the energy potential in an area such as wind energy, sunlight, water and many more can be used for electrical generation. Integration of new renewable energy generation system will improve the capacity and reliability of the electrical system. Among renewable energy generation systems, the most often being integrated are photovoltaic and wind turbine [1][3].

Hybrid renewable energy power system with a standalone system need energy storage equipment. There are a variety of technologies to store electrical energy. One of them is electrolyzer technology for hydrogen production [4], [5]. Hydrogen will be used for generating electrical energy using fuel cell technology [6]-[8]. The energy produced by the fuel cell technology will be used to supply electrical energy when needed.
In the DC Bus system, the important parameters that must be controlled is the voltage. The DC bus voltage stability will determine the quality of the power system. PV - wind - fuel cell electrolyzer hybrid system, PV and wind turbine is expected to generate a lot of energy. Therefore it takes control of the MPPT (Maximum Power Point Tracking) to maximize power when its main energy source, that is sunlight and wind change a lot. However, when the condition of the renewable energy source and load is fluctuating, then the output voltage of the converter is not constant. Therefore, additional unit which serve to control DC bus voltage is required in order to remain stability when any change occurred. In this case, the role of voltage control in DC bus performed by the electrolyzer and fuel cell.

Hybrid system flexibility depends on the type and control system used. The more complex the system and the more units the integrated plant is, it will increase the complexity of control system if the control system is controlled by an integrated control. The integration of each of the renewable energy plant would be easier to do if each unit of the plant using a local controller. Local controller in each part will make the system become flexible. If there are additional generating units, it can be done easily without changing the existing control system. New generating units can be directly connected to the DC grid. To control the power generated by generating units from renewable energy sources need a good control system in order to keep balance of power and efficiency of the system. Some research applied control technique using causal ordering graph on hydrogen production process [5]. When the power genej ration surplus, Electrolyzer is used to breaks water into hydrogen and oxygen gas. The hydrogen is save on hydrogen tank.

\section{SYSTEM CONFIGURATION}

Standalone hybrid PV/WTGS/Fuel cell generation system integrated with electrolyzer system is shown in figure 1. All the hybrid components are integrated on DC bus.

\section{A. Solar Power Generation System}

The solar panel or PV is a device that can convert solar energy into electrical energy. PV need DC-DC converter to transfer and control the output power to the DC bus. In this case, high step up boost converter topology has been chosen. 


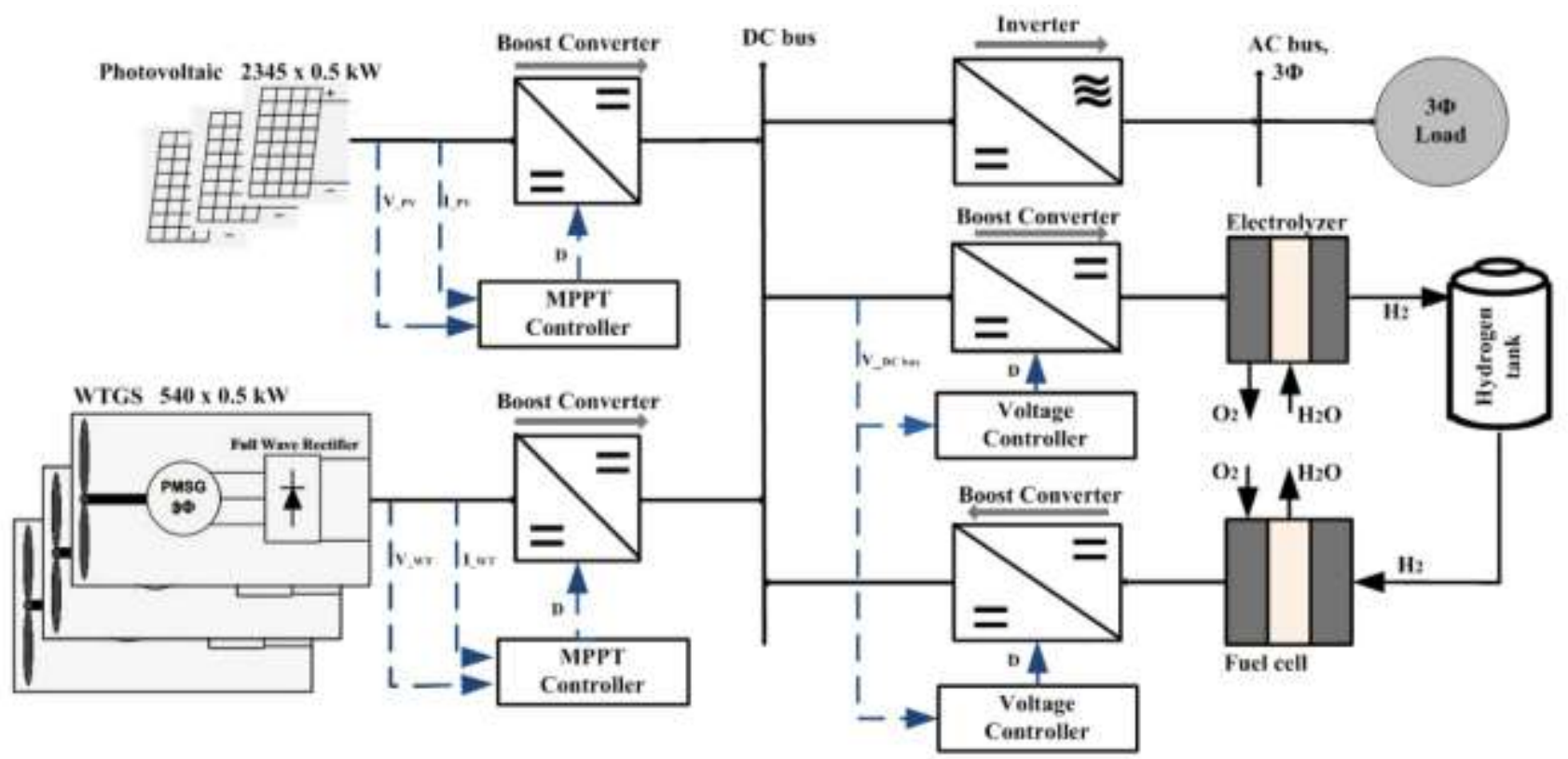

Fig. 1 Hybrid PV/Wind/Fuel cell/Electrolyzer system

The DC-DC boost converter topology (see figure 2) which is used in this research has been discussed before [10]. The control system used to manage the power flow and hydrogen flow. A model predictive control (MPC) is developed to control hydrogen production by electrolyzer using the power generated by The wind turbine and the wave energy [4]. The main elements in MPC are the objective function to be minimized, the model used to compute the predictions of the controlled variables, the definition of the process constraints and the method applied to solve the optimization problem. The reversible voltage of the PEM fuel cell may be calculated from the energy balance between the reactants and products, and the Faraday's constants [6]. The model includes the phenomena like activation polarization, ohmic polarization, and mass transport effect present in a PEM fuel cell [7]. Investigate the effect of different operating parameters such as pressure, temperature, membrane thickness and current density of the fuel cell on the outputs of the fuel cell [9]

DC-DC boost converter need a control system to control the output voltage or output power transfer. To extract the maximum power generated by PV modules, DC-DC boost converter is operated by an MPPT control. MPPT control algorithm which is used here is perturb and observe $(\mathrm{P} \& \mathrm{O})$ algorithm with variable step size [11].

\section{B. Wind Turbine Generation System}

Wind turbine generation system consist of wind turbine, gearbox, permanent magnet synchronous generator (PMSG), 3 phase AC/DC uncontrolled rectifier and DC-DC boost converter are connected to the DC bus. The DC-DC boost converter topology which is used here is similar with solar power generation system [10]. DC/DC boost converter is operated by an MPPT control to extract maximum power from the wind generation system. S1 is electronic switch, N1 and N2 are primary and secondary side of coupled inductor, $\mathrm{Lm}$ is inductance magnetization of coupled inductor, Lk1 and Lk2 are leakage inductance of coupled inductor, D1, D2 and D3 are diodes. C0, C1 and C2 are capacitors. Fuel cell

\section{Fuel Cell}

Fuel cells are electrochemical device to convert hydrogen energy into electrical energy. Fuel cell works with two electrode as cathode and anode, electrolyte and oxidant. Anode will bind the fuel, cathode will bind the oxidant and electrolysis process will be happened between them.

Fig. 2 High step up boost converter with couple inductor and capacitor [10]

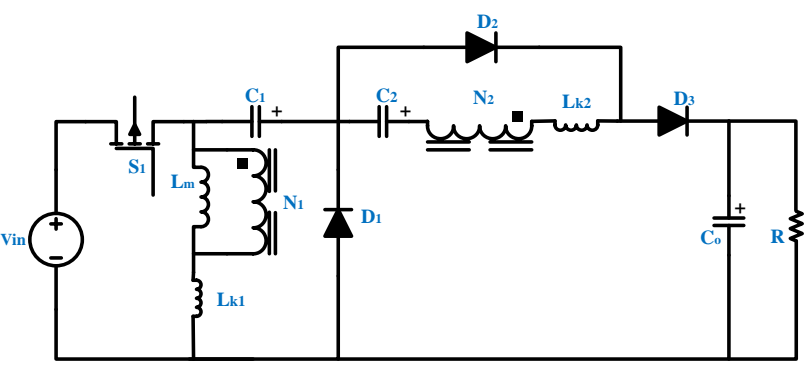

So, the electrons will flow through the load from anode to cathode. Fuel cells is connected to the DC bus through DC/DC boost converter. DC/DC boost converter with voltage control is applied to regulate voltage fluctuation. The simple circuit of fuel cells is shown in figure 2 . The FC voltage is calculated by subtracting the fuel cell losses or over voltages from the fuel cell open circuit voltage [8]. Modeling of fuel cell made with formulating the output voltage of the fuel cell comprising the reversible voltage and losses as shown in equation 1 .

$$
\mathrm{V}=\mathrm{E}+\mathrm{V}_{\text {ohmic }}+\mathrm{V}_{\text {act }}+\mathrm{V}_{\text {conc }}
$$

$\mathrm{E}$ is the reversible voltage, $\mathrm{V}_{\text {ohmic }}$ is loss caused by resistance of the membrane, $V_{\text {act }}$ is the energy used for starting chemical reaction in PEM cell, $\mathrm{V}_{\text {conc }}$ is concentration voltage drop caused by current flow in higher density. The complete explaination has been discuss in another research about PEM cell [6]-[8], [12].

\section{Electrolyzer}

Electrolyzer is electrochemical device to convert hydrogen energy into electrical energy. It works with two electrode, electrolyte and oxidant. Mechanisms of PEM electrolysis are splitting the water caused by electrochemical reaction between two electrodes. Electrolyzer is connected to the DC bus using buck converter. In this case, electrolyzer have 2 function for this hybrid system. The first is used as a storage device that save the excessive power produced by renewable power generation in hydrogen form. The second, Electrolyzer is used as a part of constant voltage control strategy when overvoltage happened on the system. To add the 
electrolyzer on the hybrid system, the electrolyzer has been modelled as shown in figure 5 .

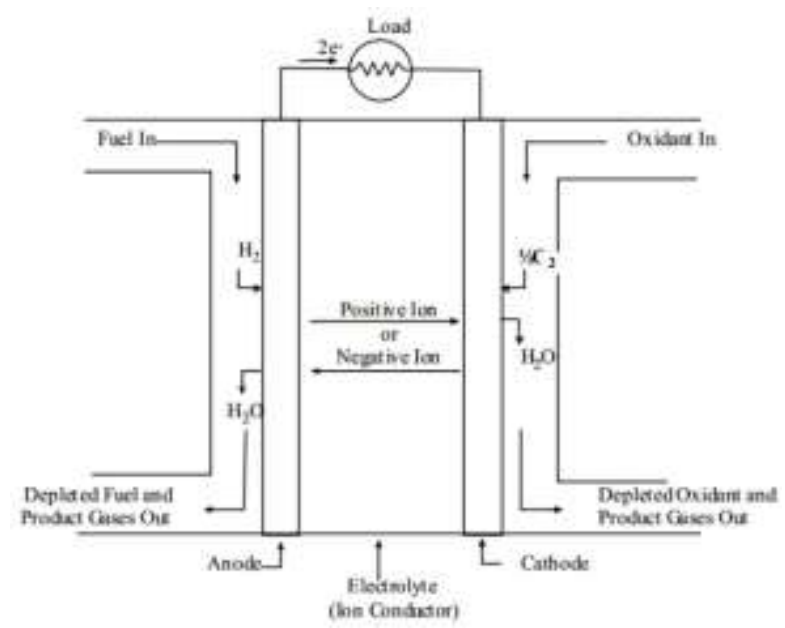

Fig. 3 Simple circuit of fuel cells

The detail explanation about equivalent circuit model of electrolyzer has been discussed [13].

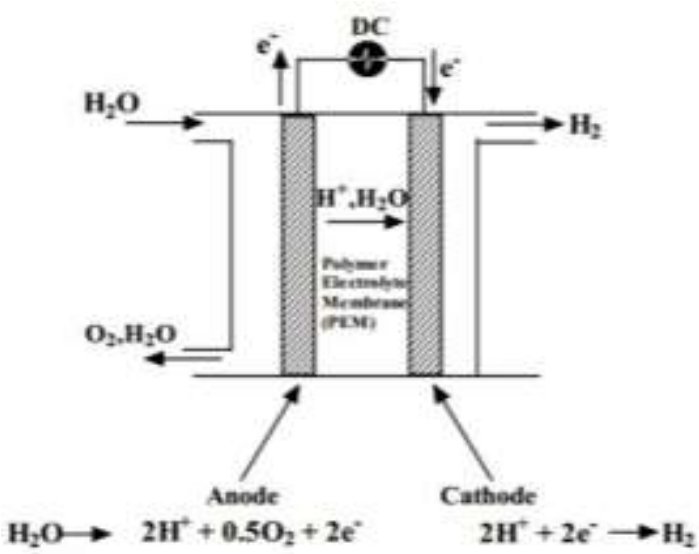

Fig. 4 PEM Electrolyzer for hydrogen production process

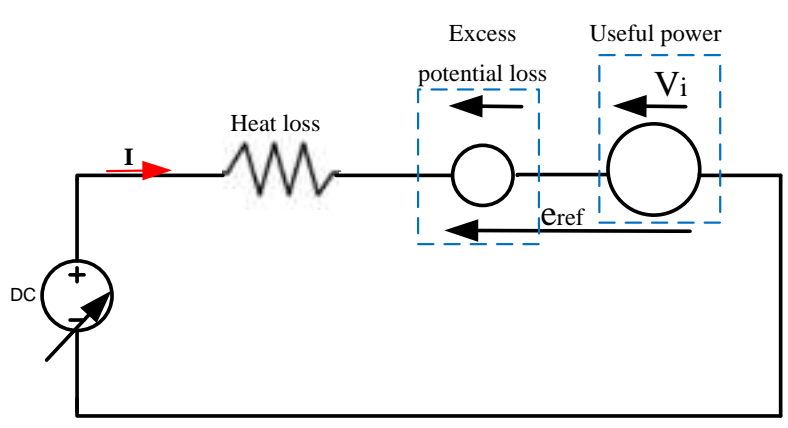

Fig 5. Equivalent circuit model of a single PEM Electrolyzer

\section{DESIGN CONTROL SYSTEM}

When observed in term of the economy, to make use of the existing energy sources, photovoltaic and WTGS must be capable of generating maximum power. So MPPT control is needed. While $D C$ bus voltage will always changing according to the changes of power that goes in and out of the system. To overcome this case, fuel cell and electrolyzer acted to keep the DC bus voltage remains stable.

\section{A. MPPT Control Design of PV and Wind Generator}

MPPT control is a technique of power seeking control to optimize the value of power always reach its maximum point. The basic concept of MPPT control is by tracking the maximum power point of a power plant. Voltage and current output from the plant is measured and processed by controller using MPPT algorithm to generate PWM control signal. The form of this PWM control signal is duty cycle which will be used to trigger electronic switch of the converter. In this case, Incremental Conductance (IC) has been chosen for MPPT control technique algorithm [11]. Incremental conductance is one of MPPT control methods that have minimum steady state error and fast response to reach convergence value. Beside that, the controller will adjust the PWM signal to increase or decrease the operating voltage across PV array modules and wind turbine generation until reach the maximum power point (MPP). The result can reach maximum value when the derivative of power (dP) respect to the current (I) or voltage (V) is null. The expression is shown in eq. 2 and eq. 3 .

$$
\begin{aligned}
& \frac{d P}{d V}=\frac{d(V I)}{d V}=I \frac{d V}{d V}+V \frac{d I}{d V}=I+V \frac{d I}{d V} \\
& \frac{d P}{d I}=\frac{d(V I)}{d I}=I \frac{d V}{d I}+V \frac{d I}{d I}=V \frac{d V}{d I}+V
\end{aligned}
$$

The flowchart of the variable step IC MPPT control is shown in figure 7 and the control diagram is shown in figure $6 . \mathrm{V}(\mathrm{k})$ and $\mathrm{I}(\mathrm{k})$ is the present voltage and current measurement, $\mathrm{V}(\mathrm{k}-1)$ and $\mathrm{I}(\mathrm{k}-1)$ is the past voltage and current measurement, $\mathrm{P}(\mathrm{k})$ and $\mathrm{D}(\mathrm{k})$ is the present power and duty cycle, $\mathrm{P}(\mathrm{k}-1)$ and $\mathrm{D}(\mathrm{k}-1)$ is the past power and duty cycle and $\mathrm{N}$ is the constant multiplier. V_PV and I_PV is voltage and current unit of photovoltaic, V_WT and I_ is voltage and current unit of WTGS and P_mpp is the maximum power point of a generation.

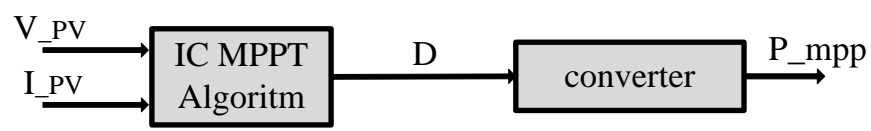

(a)

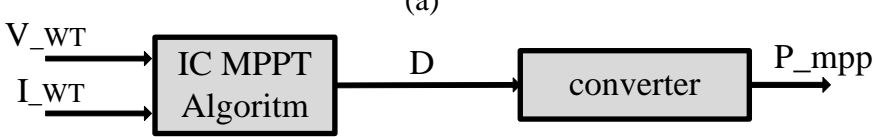

(b)

Fig. 6 MPPT control diagram, a) for PV; b) for WT

\section{B. Constant Voltage Control Design}

Constant voltage control is a control technique which is used to maintain voltage remains constan to match the voltage reference. The basic concept of constant voltage control is to control the PWM signal by measuring the difference in voltage measured with the reference voltage as the input signal control of PI controller. The output voltage of the converter are measured and fed to the controller. Then the controller will produce PWM signal to keep the output voltage of the converter remains constan.

The basic concept in the DC bus voltage setting on this hybrid system is divided into two conditions, that is by raising the voltage when the DC bus undervoltage and lowers the voltage when the DC bus is overvoltage. Undervoltage condition occur when the total power produced by renewable energy generators is less than the power that the load needed. Whereas the condition of overvoltages occurs when the total power produced by renewable energy generators is more than the power that the load needed 


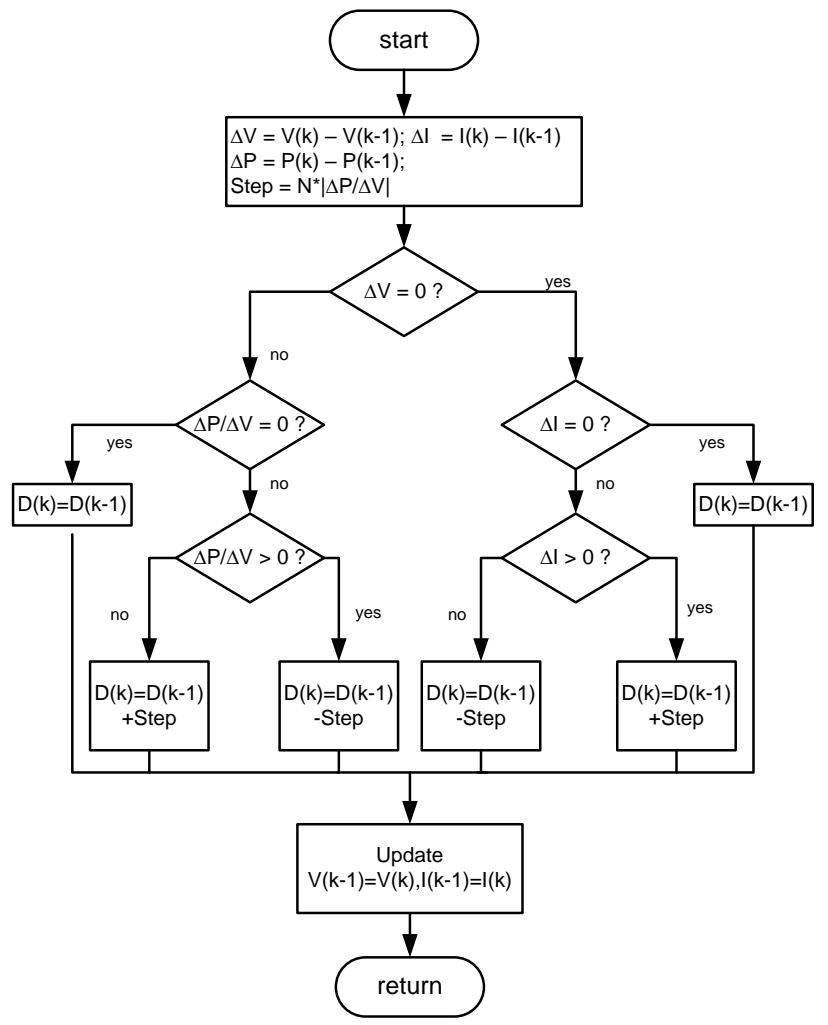

Fig. 7 Variable step incremental conductance algoritm[11]

Fig. 8 Power operation range of single PV array, WTGS, Fuel cell and POWER GENERATION - DC BUS VOLTAGE CURVE

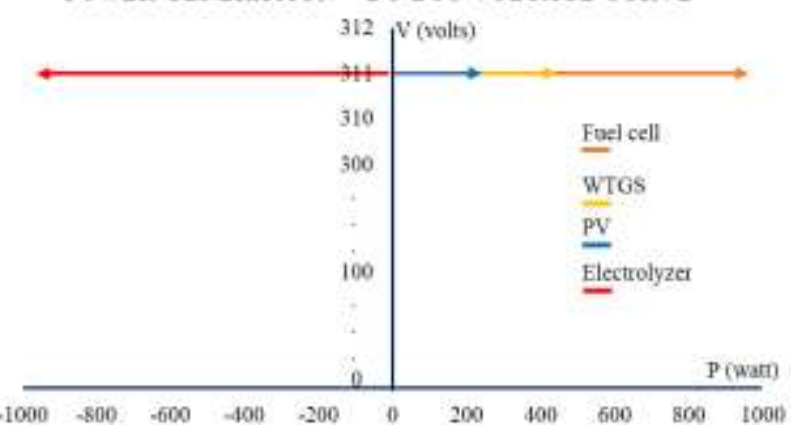

Electrolyzer vs DC bus voltage

The DC bus voltage setting is done by 2 components that work interchangeably. The components is fuel cell and electrolyzer. When fuel cell working, the electrolyzer should go on stand by mode and vice versa. Fuel cell will work to raise the voltage when undervoltage happen untul the DC bus voltage reach the reference voltage (311 Volts). Electrolyzer will work to lower the voltage when the overvoltage happen untul the DC bus voltage reach the reference voltage (311 Volts).

So it can be concluded that a stable voltage 311 Volts is obtained when there is a balance of power (the amount of power generated by renewable energy power plant in proportion to the power consumed) as in equation 4 . In this case, the power generated by renewable energy power plant is power generated by PV and WTGS. The power consumption is the amount of power that cunsumed by the load and the electrolyzer for hydrogen production.

$$
\begin{aligned}
& \mathrm{P}_{\text {generation }}=\mathrm{P}_{\text {demand }} \\
& \mathrm{P}_{\text {generation }}=\mathrm{P}_{\mathrm{PV}}+\mathrm{P}_{\text {WTGS }}+\mathrm{P}_{\text {fuel cell }} \\
& \mathrm{P}_{\text {demand }}=\mathrm{P}_{\text {load }}+\mathrm{P}_{\text {electrolyzer }}
\end{aligned}
$$

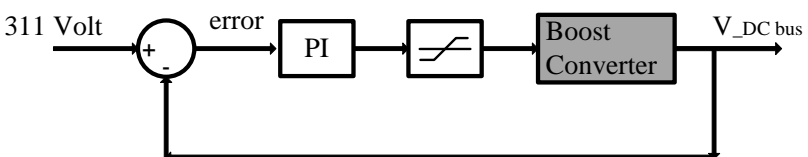

(a)

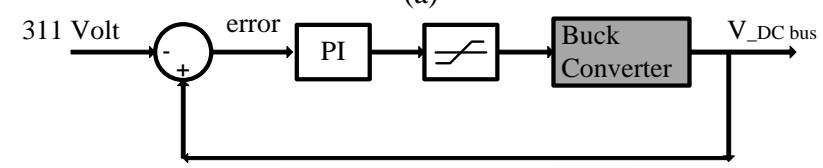

(b)

Fig. 9 Block Diagram Control at, a) Fuel Cell Converter b) Electrolyzer Converter

\section{SIMULATION RESULT AND DISCUSSION}

The result of the simulation and discussion of the PV, WTGS, electrolyzer and fuel cell hybrid system control will be shown in this section. Goals and purpose of the MPPT control system of PV and WTGS is to maximize the power generated. Consequently, the DC bus voltage response will uncontrollably fluctuate when the load change or when the power generated by the PV system and WTGS are changed. To overcome the the uncontrolled fluctuations in DC bus voltage, the use of fuel cell and electrolyzer is one of the suitable choice to be applied. The parameters used in the hybrid system

\begin{tabular}{|c|c|c|c|}
\hline $\begin{array}{l}\text { Parameters of } \\
\text { Fuel cell }\end{array}$ & value & $\begin{array}{l}\text { Parameters of } \\
\text { electrolyzer }\end{array}$ & Value \\
\hline $\mathrm{V}_{\mathrm{o}-\mathrm{FC}}$ & $40 \mathrm{~V}$ & $\mathrm{~V}_{\mathrm{o}-\mathrm{FC}}$ & $40 \mathrm{~V}$ \\
\hline $\mathrm{I}_{\mathrm{o}-\mathrm{FC}}$ & $25 \mathrm{~A}$ & $\mathrm{I}_{\mathrm{o}-\mathrm{FC}}$ & $25 \mathrm{~A}$ \\
\hline $\mathrm{P}_{\mathrm{o} \text {-nom }}$ & $1 \mathrm{~kW}$ & $\mathrm{P}_{\mathrm{o}-\mathrm{nom}}$ & $1 \mathrm{~kW}$ \\
\hline $\begin{array}{l}\text { Parameters of } \\
\text { PV array }\end{array}$ & value & $\begin{array}{l}\text { Parameters of } \\
\text { PV converter }\end{array}$ & value \\
\hline $\mathrm{P}$ & $4 \times 60 \mathrm{Wp}$ & $\mathrm{P}$ & $250 \mathrm{~W}$ \\
\hline $\mathrm{V}_{\mathrm{oc}}$ & $84,4 \mathrm{~V}$ & $\mathrm{~V}_{\text {in-min }}$ & $30 \mathrm{~V}$ \\
\hline $\mathrm{V}_{\mathrm{mpp}}$ & $68,4 \mathrm{~V}$ & $\mathrm{~V}_{\text {in-max }}$ & $85 \mathrm{~V}$ \\
\hline $\mathrm{I}_{\mathrm{sc}}$ & $3,8 \mathrm{~A}$ & $\mathrm{~V}_{\text {out }}$ & $311 \mathrm{~V}$ \\
\hline $\mathrm{I}_{\mathrm{mpp}}$ & $3,5 \mathrm{~A}$ & $\mathrm{f}_{\mathrm{sw}}$ & $20 \mathrm{kHz}$ \\
\hline \multirow[t]{3}{*}{$\mathrm{T}$} & $25^{\circ}$ & $\mathrm{N}$ & 3 \\
\hline & & $\Delta \mathrm{I}_{\mathrm{L}-\mathrm{pp}} / \mathrm{I}_{\mathrm{L}}$ & $10 \%$ \\
\hline & & $\Delta \mathrm{I}_{\mathrm{L}-\mathrm{pp}} / \mathrm{I}_{\mathrm{L}}$ & $0,01 \%$ \\
\hline $\begin{array}{l}\text { Parameters of } \\
\text { WT }\end{array}$ & value & $\begin{array}{l}\text { Parameters of } \\
\text { WT converter }\end{array}$ & value \\
\hline Pmech & $635 \mathrm{~W}$ & $\mathrm{P}$ & $500 \mathrm{~W}$ \\
\hline Pelect & 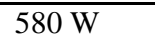 & Vin-min & $30 \mathrm{~V}$ \\
\hline Wind speed & $8 \mathrm{~m} / \mathrm{s}$ & Vin-max & $60 \mathrm{~V}$ \\
\hline \multirow{5}{*}{$\begin{array}{l}\text { Rotational } \\
\text { speed }\end{array}$} & $554 \mathrm{rpm}$ & Vout & $311 \mathrm{~V}$ \\
\hline & & fsw & $20 \mathrm{kHz}$ \\
\hline & & $\mathrm{N}$ & 2 \\
\hline & & $\Delta \mathrm{IL}-\mathrm{pp} / \mathrm{IL}$ & $10 \%$ \\
\hline & & $\Delta \mathrm{IL}-\mathrm{pp} / \mathrm{IL}$ & $0,01 \%$ \\
\hline
\end{tabular}
control simulation evaluate in the table 1 .

Table 1. Simulation Parameters

The solar panel configuration used is $4885 \mathrm{PV}$ arrays with one array consist of 4 solar panels with a capacity of 60 watts connected in series. While the WTGS used is 540 units with a capacity of 500 watts per unit. 500 fuel cells and 1000 electrolyzers. The number of each of these units is determined by the optimization algorithm using PSO. 


\section{A. MPPT Control Response}

Based on the characteristic curve of V-I solar panel and WTGS shows changes in power rating when the operating output voltage and current change. From variations in voltage and current of PV and WTGS operations, there is a power point that has the greatest value among the others. With the help of current and voltage sensors, the output current and voltage of PV and WTGS are measured and processed by the controller. The controller has been programmed with the Incremental Conductance algorithm program with step variables. With one of these MPPT algorithms, the Controller will produce a control signal in the form of a PWM signal that can regulate the output power of PV and WTGS so that it is always the maximum value even if the energy source conditions change. Simulation results from MPPT controls on PV and WTGS are shown in Figure 10.

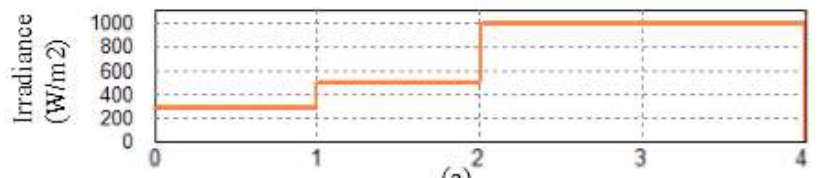

(a)

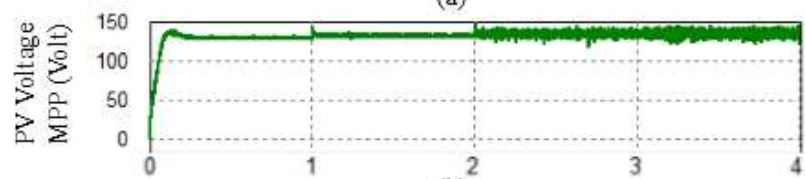

(b)

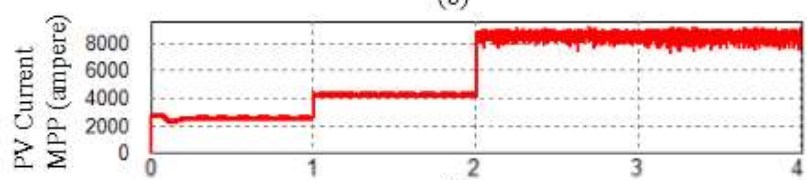

(c)

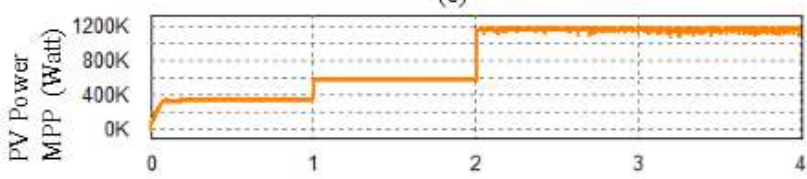

(d)

Time (s)

Fig. 10 a) Solar irradiation ; b) output voltage PV array; c) output current of all PV module; d) Output Power of all PV array module.

From Figure 10 it can be seen that each level of irradiation has a different maximum power operating point that can be produced by solar panels. When the irradiation level is of maximum value $(1000 \mathrm{~W} / \mathrm{m} 2)$, a single array of solar panels can produce maximum power according to its capacity (240 watts). When the level of solar irradiation changes, the MPPT control will condition the power operation to remain maximal according to the characteristics of the solar panel power operation shown in Figure 4. The search process for the maximum power generated is done by adjusting the converter load by changing the duty cycle of the converter with input parameters in the form of voltage and current terminal solar panels. When the generated power has a maximum value, the controller will maintain the duty cycle. When irradiation changes, the controller will detect changes in input power and the duty cycle will be changed to find the maximum power point. When viewed from the response of its changes, the stability of the system's power decreases when there is an increase in sunlight irradiation.

From figure 11 it can be concluded that the power generated by WTGS can be maximized with MPPT control when the wind speed conditions change. This process is carried out by measuring the voltage and current output from WTGS to produce a trigger signal in the form of a duty cycle control in the converter. From the power response generated by WTGS, WTGS output power fluctuations are still quite large. The greater the wind speed, the more unstable the system will be.
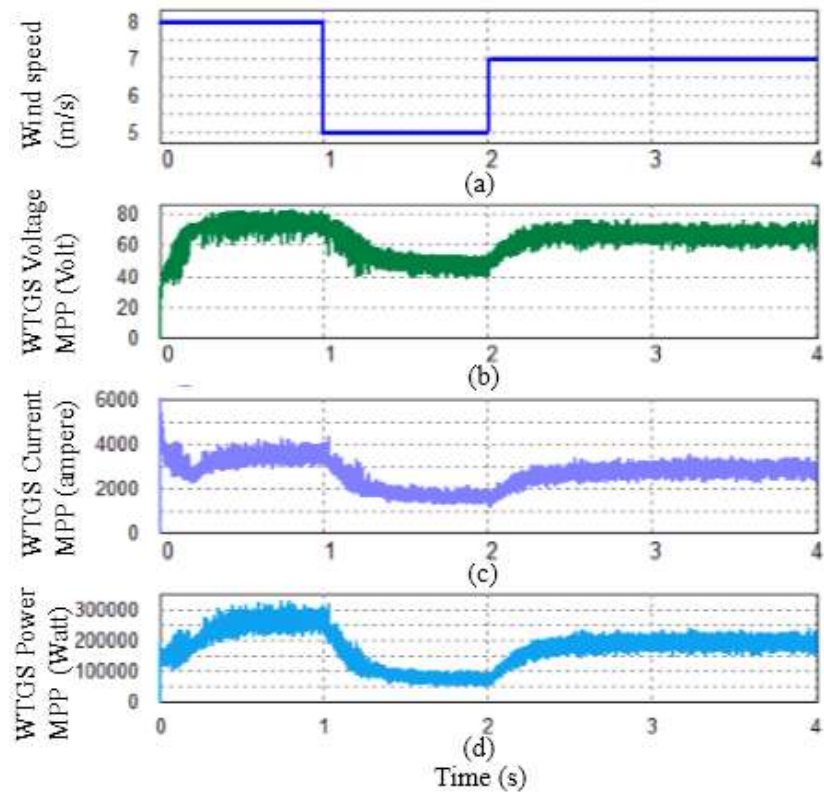

Fig. 11 a) wind speed; b) output voltage of WTGS; c) output current of all WTGS; d) Output Power of all WTGS.

\section{B. Constant Voltage Control Response}

From figure 12, it can be seen that this hybrid system is tested with input power from PV and WTGS that are constant with a changing load power. in this test the DC bus voltage shows a constant value when the load changes as shown in figure $12 \mathrm{f}$. This constant value is obtained by adjusting the load on the converter in the fuel cell and converter in the electrolyzer. Figure $12 \mathrm{~d}$ shows that the power stability released by the fuel cell is very low. This is indicated by a large enough fuel cell output fluctuation. The power absorbed by the electrolyzer for the hydrogen production process can be seen in figure 12e. From the picture it can be concluded that the electrolyzer system power fluctuations are very low.

From figure 13a show the DC bus voltage ripple around 1 volt $(0,32 \%)$. White in figure $13 \mathrm{~b}$ shows the output voltages of inverter which is equipped with a passive LC filter to produce 3 phase sinusoidal voltage.

\section{CONCLUSION}

According to the simulation result, it can be concluded that MPPT control system can work well. PV and WTGS are capable of being operated at their maximum power point. But the greater the power generated, the greater the stability of the power released by the converter. This applies to PV and WTGS. While constant voltage control works well. This is evidenced by the DC voltage of the bus remaining constant 311 volts even though the input power and load change. The electrolyzer works to regulate hydrogen production when the bus DC voltage level exceeds 311 volts. When the DC bus voltage level is below 311 volts, the fuel cell will provide power input to the system so that the system will still be able to maintain a voltage level of 311 volts. The system has good power quality as evidenced by the small DC bus voltage ripple $0.32 \%$ and the inverter output voltage in the form of 3 phase sinusoidal voltage. 
JAREE-Journal on Advance Research in Electrical Engineering Volume3, Number 2, October 2019
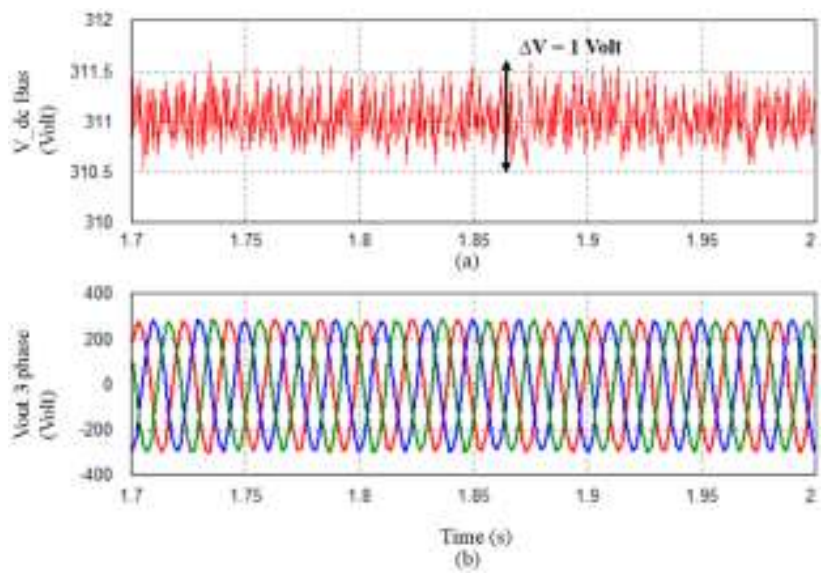

Fig. 12 a) load demand; b) PV power; c) WTGS power; d) Fuel cell power; e) electrolyzer power; f) DC bus voltage.

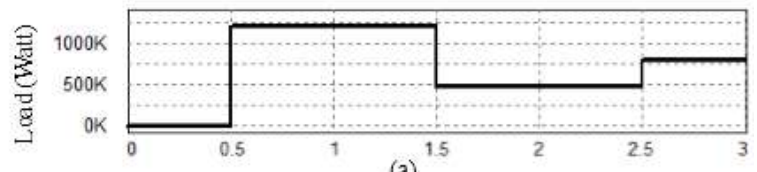

(a)

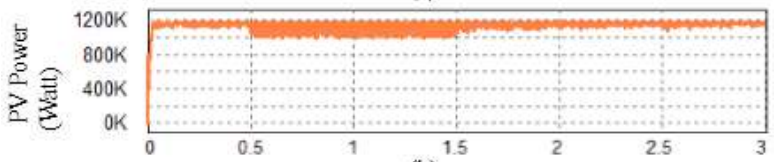

(b)

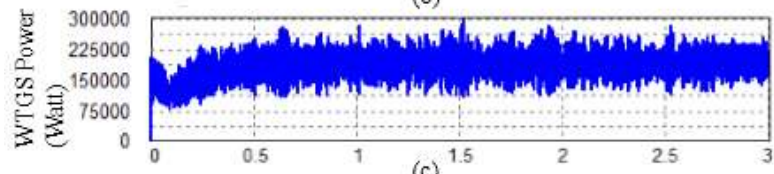

(c)
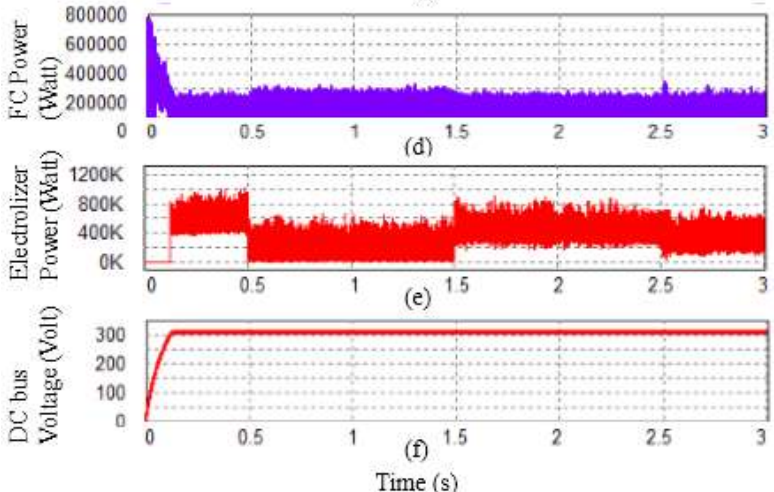

Fig. 13 a) DC bus voltage ripple; b) 3 phase output voltage

\section{REFERENCES}

[1] J. Plaza Castillo, C. Daza Mafiolis, E. Coral Escobar, A. Garcia Barrientos, and R. Villafuerte Segura, "Design, Construction and Implementation of a Low Cost Solar-Wind Hybrid Energy System," IEEE Lat. Am. Trans., vol. 13, no. 10, pp. 3304-3309, Oct. 2015.

[2] R. Selvam, "A Novel Method for Hybrid Solar/Wind/Battery Power Generation for Rural Electrification System," Int. J. Res. Appl. Sci. Eng. Technol., vol. V, no. XI, pp. 211-216, Nov. 2017.

[3] K. Strunz, E. Abbasi, and D. N. Huu, "DC Microgrid for Wind and Solar Power Integration," IEEE J. Emerg. Sel. Top. Power Electron., vol. 2, no. 1, pp. 115-126, Mar. 2014.
[4] E. Özgirgin, Y. Devrim, and A. Albostan, "Modeling and simulation of a hybrid photovoltaic (PV) module-electrolyzer-PEM fuel cell system for micro-cogeneration applications," Int. J. Hydrog. Energy, vol. 40, no. 44, pp. 15336-15342, Nov. 2015.

[5] A. H. A. Rahim, A. S. Tijani, F. H. Shukri, S. Hanapi, and K. I. Sainan, "Mathematical modelling and simulation analysis of PEM electrolyzer system for hydrogen production," in 3rd IET International Conference on Clean Energy and Technology (CEAT) 2014, 2014, pp. 1-7.

[6] M. Ay, A. Midilli, and I. Dincer, "Thermodynamic modelling of a proton exchange membrane fuel cell," Int. J. Exergy, vol. 3, no. 1, p. $16,2006$.

[7] D. Yu and S. Yuvarajan, "Electronic circuit model for proton exchange membrane fuel cells," J. Power Sources, vol. 142, no. 1-2, pp. 238242, Mar. 2005.

[8] J. T. Pukrushpan, A. G. Stefanopoulou, and H. Peng, "Modeling and control for PEM fuel cell stack system (I)," p. 6.

[9] F. Liu, S. Duan, F. Liu, B. Liu, and Y. Kang, "A Variable Step Size INC MPPT Method for PV Systems," IEEE Trans. Ind. Electron., vol. 55 , no. 7, pp. 2622-2628, Jul. 2008

[10] K. Shah, V. Gaur, S. Joshi, and N. Patel, "Maximum Power Point Tracking Methods for Wind and Solar Conversion Systems for Standalone Generation PSIM based Perturb and Observe Method," Int. J. Eng. Res. Dev. IJERD, 2015

[11] M. Ridwan, A. Pradipta, S. Anam, and M. Ashari, "Comparison of P amp;O and inceremental conductance based maximum power point tracking for wind turbine application in remote area (Case study: Gili genting Island, Madura, East Java, Indonesia)," in 2018 IEEE International Conference on Innovative Research and Development (ICIRD), 2018, pp. 1-6.

[12] A. M. O. Haruni, M. Negnevitsky, M. E. Haque, and A. Gargoom, “A Novel Operation and Control Strategy for a Standalone Hybrid Renewable Power System," IEEE Trans. Sustain. Energy, vol. 4, no. 2, pp. 402-413, Apr. 2013.

[13] T. Zhou, B. Francois, M. el hadi Lebbal, and S. Lecoeuche, "Modeling and Control Design of Hydrogen Production Process by Using a Causal Ordering Graph for Wind Energy Conversion System," in 2007 IEEE International Symposium on Industrial Electronics, 2007, pp. 3192-3197.

[14] A. Serna, J. E. Nonney-Rico, and F. Tadeo, "Model predictive control of hydrogen production by renewable energy," in IREC2015 The Sixth International Renewable Energy Congress, 2015, pp. 1-6.

[15] T. Abdul Hussain Ratlamwala, "Energy and exergy analyses of an integrated fuel cell and absorption cooling system," Sep. 2010.

[16] S. M. Chen, T. J. Liang, L. S. Yang, and J. F. Chen, "A Boost Converter With Capacitor Multiplier and Coupled Inductor for AC Module Applications," IEEE Trans. Ind. Electron., vol. 60, no. 4, pp. 1503-1511, Apr. 2013.

[17] J. M. Lee and B. H. Cho, "A Dynamic Model of a PEM Fuel Cell System," p. 5

[18] O. Atlam and M. Kolhe, "Equivalent electrical model for a proton exchange membrane (PEM) electrolyser," Energy Convers. Manag., vol. 52, no. 8-9, pp. 2952-2957, Aug. 2011

[19] A. Nekkache, B. Bouzidi, A. Kaabeche, and Y. Bakelli, "Hybrid PVWind based water pumping system optimum sizing: a PSO-LLP-LPSP optimization and cost analysis," in 2018 International Conference on Electrical Sciences and Technologies in Maghreb (CISTEM), 2018, pp. 1-6. 